\title{
Potassium bromate-induced cell model of age-related macular degeneration in vitro
}

\author{
SHU-CHUN KUO ${ }^{1,2}$, YINGXIAO LI ${ }^{3}$, KAI-CHUN CHENG ${ }^{4}$, CHIA-CHEN HSU ${ }^{5,6}$, \\ JUEI-TANG CHENG ${ }^{2}$ and HUI-HSUAN LAU ${ }^{7}$
}

\author{
${ }^{1}$ Department of Optometry, Chung Hwa University of Medical Technology, Tainan City 71701; \\ ${ }^{2}$ Department of Ophthalmology, Chi-Mei Medical Center, Tainan City $71003 ;{ }^{3}$ Department of Nursing, \\ Tzu Chi University of Science and Technology, Hualien City 97005, Taiwan, R.O.C.; \\ ${ }^{4}$ Department of Psychosomatic Internal Medicine, Kagoshima University Graduate School of Medical and Dental Sciences, \\ Kagoshima 890, Japan; ${ }^{5}$ Graduate Institute of Gerontology and Health Care Management, \\ Chang Gung University of Science and Technology, New Taipei City 11049; ${ }^{6}$ Department of Otorhinolaryngology, \\ Taipei City Hospital, Tainan City 10413; ${ }^{7}$ Department of Obstetrics and Gynecology, \\ Mackay Memorial Hospital, Taipei City 10449, Taiwan, R.O.C.
}

Received June 25, 2020; Accepted November 23, 2020

DOI: $10.3892 / \mathrm{mmr} .2021 .11855$

\begin{abstract}
Age-related macular degeneration (AMD) progression occurs due to oxidative stress in retinal pigment epithelium (RPE) cells. To develop a new model of AMD, the present study investigated the effects of potassium bromate $\left(\mathrm{KBrO}_{3}\right)$ on ARPE-19 cells. Incubation with $\mathrm{KBrO}_{3}$ for $24 \mathrm{~h}$ significantly decreased ARPE-19 cell viability in a concentration-dependent manner compared with the control group. The MTT and lactate dehydrogenase assay results indicated that $\mathrm{KBrO}_{3}$ induced cell apoptosis. Compared with the control group, $\mathrm{KBrO}_{3}$ treatment significantly decreased the $\mathrm{Bcl} 2 / \mathrm{Bax}$ ratio, as determined via western blotting, and caspase-3 mRNA expression levels. Fluorescence microscopy indicated the increased ROS levels in cells treated with $\mathrm{KBrO}_{3}$. Endogenous antioxidant enzyme activities, including superoxide dismutase and glutathione peroxidase, were significantly inhibited by $\mathrm{KBrO}_{3}$ compared with the control group. Moreover, the antioxidants tiron and phloroglucinol inhibited $\mathrm{KBrO}_{3}$-mediated effects on ARPE-19 cells in a dose-dependent manner. Additionally, GPR109A is the binding site of 4-hydroxynonenal (4-HNE). $\mathrm{KBrO}_{3}$ displayed cytotoxic effects in 293 cells, which naturally lack the GPR109A
\end{abstract}

Correspondence to: Professor Juei-Tang Cheng, Department of Ophthalmology, Chi-Mei Medical Center, 901 Zhonghua Road, Yong Kang, Tainan City 71003, Taiwan, R.O.C.

E-mail: jtcheng5503@gmail.com

Dr Hui-Hsuan Lau, Department of Obstetrics and Gynecology, Mackay Memorial Hospital, 92 Zhongshan North Road, Taipei City 10449, Taiwan, R.O.C.

E-mail: huihsuan1220@gmail.com

Key words: age-related macular degeneration, antioxidant, reactive oxygen species, potassium bromate, retinal pigment epithelium cells gene, but these effects were not observed in 4-HNE-treated 293 cells, suggesting that $\mathrm{KBrO}_{3}$ induced apoptosis without increasing endogenous 4-HNE levels in cells. Moreover, the results suggested that $\mathrm{KBrO}_{3}$-induced oxidative stress may activate STAT3 to increase VEGF expression in ARPE-19 cells. Collectively, the results of the present study supported the potential use of $\mathrm{KBrO}_{3}$ to induce an in vitro model of AMD in ARPE-19 cells.

\section{Introduction}

Aging and other factors, including increased oxidative stress and chronic inflammation, can diminish the function of the retinal pigment epithelium (RPE), which is located between the photoreceptors and vascular choroid in the eye, leading to eventual degeneration (1). Degenerated RPE cells may cause irreversible injury to photoreceptors and a disturbance in central vision, resulting in age-related macular degeneration (AMD) (2).

AMD is a progressive disease associated with retinal degeneration that can cause irreversible vision loss in elderly populations. A gradual increase in the prevalence of AMD has been observed among older individuals (3). AMD is a complex and multifaceted disease that is caused by a combination of genetic and environmental factors (4). Drusen accumulation in the macula between the RPE and Bruch's membrane has been observed in the early stages of AMD (4). Subsequently, AMD progresses to interconvertible 'dry' and 'wet' forms in the later stages (5). Dry AMD is characterized by the extensive loss of RPE cells, the overlying photoreceptors and the underlying choriocapillaris (6). Therefore, RPE cell degeneration by factors including increased oxidative stress and chronic inflammation may promote the irreversible injury of photoreceptors and loss of central vision, thus inducing AMD (7). However, at present, no effective treatment is available for AMD (8). Therefore, developing a new AMD model to 
investigate strategies for the prevention or delayed progression of the disease is important.

Oxidative stress is an important factor in the pathogenesis of AMD (9) that may initiate RPE cell damage, resulting in chronic inflammation (10). RPE cells can digest photoreceptor outer rod segments (POSs); however, the digestive rate of POSs decreases during oxidative stress, resulting in accumulated POS, which promotes lipofuscin formation, one of the major pathological alterations observed in AMD (11). Therefore, reducing oxidative stress may serve as a potential therapeutic strategy to prevent AMD.

Hydrogen peroxide $\left(\mathrm{H}_{2} \mathrm{O}_{2}\right)$ is widely utilized to induce oxidative stress in human RPE cells (12), displaying dose- and time-dependent effects $(12,13)$. Chemical oxidants, including tert-butyl hydroperoxide (t-BHP) (14) and bisphenol A (15), are also used to induce oxidative stress in vitro. Additionally, acrolein-induced reactive oxygen species (ROS) overproduction has been employed for the induction of oxidative stress (16). RPE cells are sensitive to oxidative stress as they contain photosensitizers that produce ROS in response to visible light (10). The antioxidative effects of RPE cells decrease with age, and aged RPE cells display an oxidative burden, which is a sign of AMD progression (12).

Potassium bromate $\left(\mathrm{KBrO}_{3}\right)$ is an oxidant that is used as a food additive during the bread-baking process because it decomposes into a stable compound, potassium bromide (17). $\mathrm{KBrO}_{3}$-induced genotoxicity in HepG2 cells indicates that $\mathrm{KBrO}_{3}$ generates a variety of ROS, resulting in oxidative DNA damage (18). Additionally, $\mathrm{KBrO}_{3}$ induces an effect in cultured cardiac cells that was similar to the effect mediated by $\mathrm{H}_{2} \mathrm{O}_{2}$ (19). Superoxide anion radical generation by $\mathrm{KBrO}_{3}$ has also been observed (20). The aforementioned studies indicated that $\mathrm{KBrO}_{3}$ and $\mathrm{H}_{2} \mathrm{O}_{2}$ display the potential to induce $\mathrm{AMD}$, thus it was hypothesized that $\mathrm{KBrO}_{3}$ may be used to induce AMD in cells.

In the present study, cultured ARPE-19 cells were employed to identify the effective dose of $\mathrm{KBrO}_{3}$ and explore the possibility of developing a new model of AMD.

\section{Materials and methods}

Cell culture. The human RPE cell line (ARPE-19) was obtained from The Culture Collection and Research Center, Food Industry Research and Development Institute [Bioresource Collection \& Research Center (BCRC) no. 60383]. ARPE-19 cells were cultured in DMEM/F12 medium (Cytiva) with $10 \%$ fetal calf serum (Cytiva) and antibiotics (cat no. 15240062; Thermo Fisher Scientific, Inc.; solution contains 10,000 U/ml of penicillin, $10,000 \mu \mathrm{g} / \mathrm{ml}$ of streptomycin, and $25 \mu \mathrm{g} / \mathrm{ml}$ of Gibco Amphotericin B) at $37^{\circ} \mathrm{C}$ with $5 \% \mathrm{CO}_{2}$ (12). 293 cells (BCRC no. 60019) were cultured in minimum essential medium (MEM) (Cytiva). After $24 \mathrm{~h}$, the cell culture medium was refreshed. Following culture for $24 \mathrm{~h}$, cells were used for subsequent experiments.

Cell viability assay. ARPE-19 and 293 cell viability was assessed by performing the MTT assay (19). The purple formazan was dissolved by DMSO. Briefly, ARPE-19 and 293 cells were seeded at 5,000 cells per well in 24-well plates and incubated with $\mathrm{KBrO}_{3}(25,50$ and $75 \mu \mathrm{M}$; Sigma-Aldrich, Merck KGaA) at $37^{\circ} \mathrm{C}$ for $24 \mathrm{~h} .4$-Hydroxynonenal (4-HNE; Cayman Chemical Company) and $\mathrm{H}_{2} \mathrm{O}_{2}$ (Sigma-Aldrich; Merck KGaA) was used as a reference to assess the effects of $\mathrm{KBrO}_{3}$. Subsequently, the culture medium was refreshed and $50 \mu \mathrm{l} \mathrm{MTT}(0.5 \mathrm{mg} / \mathrm{ml})$ was added to each well for $4 \mathrm{~h}$. The absorbance was measured at a wavelength of $595 \mathrm{~nm}$ using a Synergy HT Multi-Mode Microplate Reader (BioTek Instruments, Inc.).

Additionally, the cytotoxicity effect of $\mathrm{KBrO}_{3}$ in ARPE-19 and 293 cells was assessed using the lactate dehydrogenase (LDH) release assay kit (BioVision, Inc.) as previously described (12). The number of dead cells in the medium of cultured cells was measured to evaluate LDH activity. The absorbance was measured at a wavelength of $490 \mathrm{~nm}$ using a microplate spectrophotometer.

Determination of intracellular superoxide levels. According to the previously described protocol (19), ARPE-19 cells were seeded $\left(7.5 \times 10^{3}\right.$ cells $\left./ \mathrm{ml}\right)$ into 24 -well plates and incubated for $24 \mathrm{~h}$. Following starvation in serum-free medium at $37^{\circ} \mathrm{C}$ for $4 \mathrm{~h}$, cells were incubated with increasing amounts of $\mathrm{KBrO}_{3}$ $(25,50$ and $75 \mu \mathrm{M})$ at $37^{\circ} \mathrm{C}$ for $72 \mathrm{~h}$. Superoxide levels were measured by incubating cells with dihydroergotamine (DHE; Thermo Fisher Scientific, Inc.), which reacts with intracellular superoxide ions, for $30 \mathrm{~min}$ at $37^{\circ} \mathrm{C}$. The entire field of vision was observed using an IX71 fluorescence microscope (Olympus Corporation; magnification, x200) and a DP2-BSW imaging system (Olympus Corporation). The results were quantified using ImageJ software v2.0.0 (National Institutes of Health) (21).

Assay of intracellular ROS levels. ROS levels in ARPE-19 cells were assessed using the 2',7'-dichlorodihydro-fluorescein (DCFH-DA) fluorescent probe (Sigma-Aldrich; Merck KGaA). ARPE-19 cells at $1 \times 10^{6}$ cells $/ \mathrm{ml}$ were incubated with $25 \mu \mathrm{M}$ DCFH-DA for $1 \mathrm{~h}$ at $37^{\circ} \mathrm{C}$. Cells were pretreated with tiron (1 and $5 \mu \mathrm{M}$, Sigma-Aldrich; Merck KGaA) and phloroglucinol (1 and $5 \mu \mathrm{M}$, Sigma-Aldrich; Merck KGaA) for 30 min prior to $\mathrm{KBrO}_{3}$ at $37^{\circ} \mathrm{C}$. The resulting fluorescence was measured at an excitation wavelength of $485 \mathrm{~nm}$ and an emission wavelength of $535 \mathrm{~nm}$ using a fluorescence plate reader as previously described (22).

Assay of antioxidant enzymes. Cells were harvested and sonicated at high frequency on ice. The lysates were incubated on ice for $30 \mathrm{~min}$, to ensure protein solubilization. Cell debris was centrifuged at $10,000 \mathrm{xg}$ for $20 \mathrm{~min}$ at $4^{\circ} \mathrm{C}$. Total protein concentrations were measured by bicinchoninic acid protein assay (Thermo Fisher Scientific, Inc.).

Antioxidant enzyme activities, including superoxide dismutase (SOD) and glutathione peroxidase (GSHPx), were measured in total cell protein extracts using colorimetric assay kits (cat no. K555; BioVision, Inc.) according to the manufacturer's instructions. The absorbance was measured at a wavelength of $560 \mathrm{~nm}$ using a microplate spectrophotometer.

Western blotting. Total protein was extracted from ARPE-19 and 293 cell lysates using ice-cold RIPA buffer (Thermo Fisher Scientific, Inc.) (19). Total protein concentrations were measured by bicinchoninic acid protein assay (Thermo Fisher Scientific, Inc.). Proteins $(10 \mu \mathrm{g})$ were separated by $10 \%$ or $15 \%$ SDS-PAGE and electro-transferred onto polyvinylidene fluoride membrane (EMD Millipore). After blocking with 
A

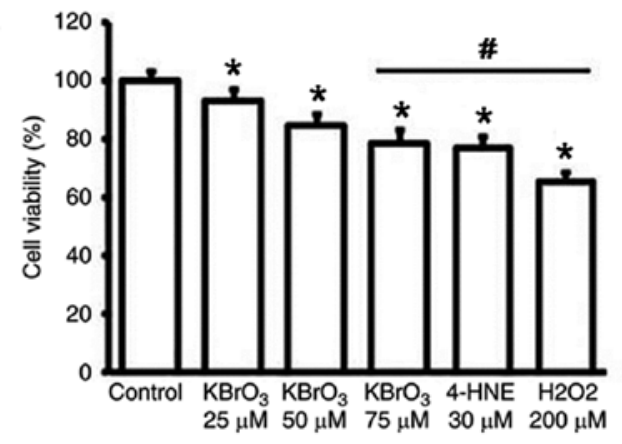

C

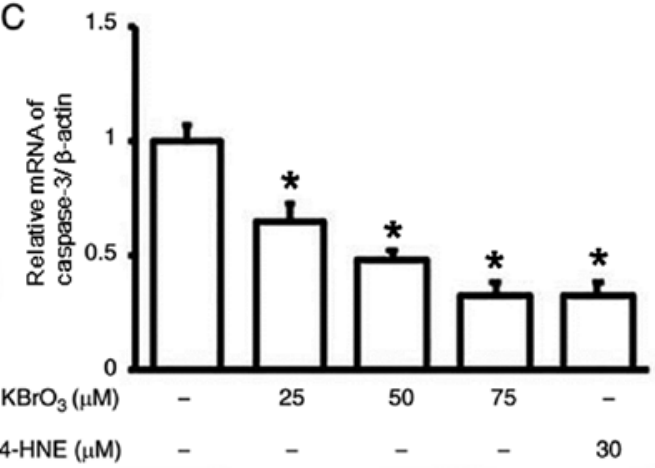

B
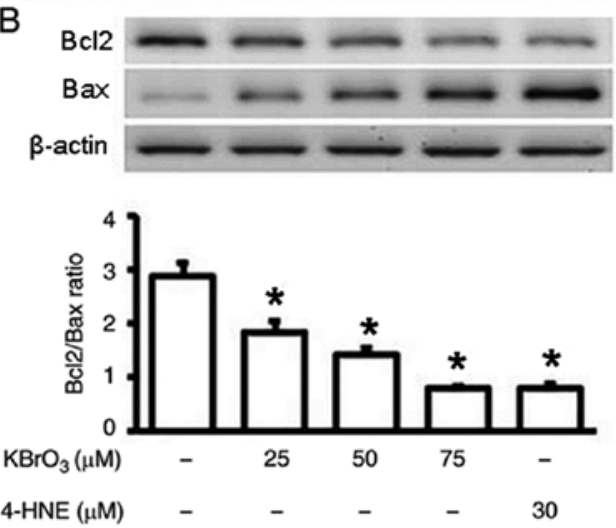

D

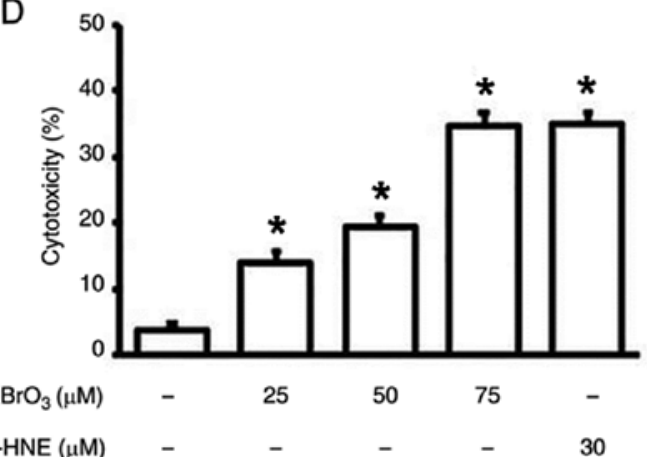

Figure $1 . \mathrm{KBrO}_{3}$ induces ARPE-19 cell injury in vitro. ARPE-19 cells were incubated with $\mathrm{KBrO}_{3}$, $4-\mathrm{HNE}_{\text {or }} \mathrm{H}_{2} \mathrm{O}_{2}$ for 24 h. (A) ARPE-19 cell viability was assessed by performing the MTT assay. ARPE-19 cell apoptosis was assessed by measuring (B) the Bcl2/Bax ratio and (C) caspase-3 mRNA expression levels. (D) ARPE-19 cell viability was also assessed by performing the lactate dehydrogenase assay. Data are presented as the mean \pm SEM ( $\mathrm{n}=6$ ). ${ }^{*} \mathrm{P}<0.05 \mathrm{vs.}$ control; ${ }^{\#} \mathrm{P}<0.05$ vs. $\mathrm{KBrO}_{3} 25 \mu \mathrm{M}$, potassium bromate; 4-HNE, 4-hydroxynonenal.

$5 \%(\mathrm{v} / \mathrm{v})$ bovine serum albumin (MDBio, Inc.) for $1 \mathrm{~h}$ at room temperature, membranes were incubated with primary antibodies, Bcl2 (cat. no. 2870, 1:1,000; Cell Signaling Technology, Inc.), Bax (cat. no. 2772, 1:1,000; Cell Signaling Technology, Inc.), phosphorylated (p-)STAT3 (cat. no. ab76315, 1:1,000; Abcam), STAT3 (cat. no. ab68153, 1:1,000; Abcam) or $\beta$-actin (cat. no. sc-1615, 1:5,000; Santa Cruz Biotechnology, Inc.) at $4{ }^{\circ} \mathrm{C}$ overnight. The membranes were then incubated with the corresponding secondary antibodies, goat anti-rabbit IgG (cat. no. 12-348, 1:5,000; Sigma-Aldrich; Merck KGaA) or goat anti-mouse IgG (cat. no. 12-349, 1:5,000; Sigma-Aldrich; Merck KGaA) at room temperature for $1 \mathrm{~h}$. Protein bands were visualized using a chemiluminescence kit (PerkinElmer, Inc.). The optical densities of the bands for Bax (18 kDa), Bcl2 $(100 \mathrm{kDa})$ and $\beta$-actin (43 kDa) were quantified using software (Gel-Pro Analyzer v4.0 software; Media Cybernetics Inc.) (23).

Reverse transcription-quantitative PCR ( $q P C R)$. VEGF mRNA expression levels in ARPE-19 cells were measured. Total RNA was extracted from ARPE-19 and 293 cells using TRIzol ${ }^{\circledR}$ reagent (Invitrogen; Thermo Fisher Scientific, Inc.). Reverse-transcriptase reactions contained $5 \mu \mathrm{g}$ of total RNA extract, $4 \mu 15 X$ PCR buffer, $1 \mu 10.1$ MDTT, $1 \mu 1$ SuperScript $^{\mathrm{TM}}$ III RT (cat. no. 18080093; Invitrogen; Thermo Fisher Scientific, Inc.), which were performed at room temperature for $10 \mathrm{~min}$, then at $42^{\circ} \mathrm{C}$ for $30 \mathrm{~min}$ and at $95^{\circ} \mathrm{C}$ for $5 \mathrm{~min}$. Subsequently, qPCR was performed using a LightCycler (Roche Diagnostics $\mathrm{GmbH})$. The qPCR reactions contained LightCycler DNA Master Hybridization Probes reaction mix (Roche Diagnostics
$\mathrm{GmbH})$ and the dual-labeled fluorescent probes. PCR cycles were: Pretreatment at $95^{\circ} \mathrm{C}$ for $10 \mathrm{sec}, 96^{\circ} \mathrm{C}$ for $10 \mathrm{sec}, 60^{\circ} \mathrm{C}$ for $30 \mathrm{sec}, 72^{\circ} \mathrm{C}$ for $1 \mathrm{sec}, 40^{\circ} \mathrm{C}$ for $30 \mathrm{sec}(45 \mathrm{cycles})$ and a final extension at $72^{\circ} \mathrm{C}$ for $10 \mathrm{~min}$. Analysis of relative gene expression data was performed using the $2^{-\Delta \Delta \mathrm{Cq}}$ method (24). The following primers were used for qPCR: VEGF forward, 5'-AGGAGGGCAGAATCATCACG-3' and reverse, 5'-CAA GGCCCACAGGGATTTTCT-3'; caspase-3 forward, 5'-CCG ACTTCCTGTATGCTTACTCTA-3' and reverse, 5'-CATGAC CCGTCCCTTGAA-3'; and $\beta$-actin forward, 5'-CTAAGGCCA ACCGTGAAAAG-3' and reverse, 5'-GCCTGGATGGCTAC GTACA-3'. VEGF mRNA, caspase-3 mRNA expression levels were normalized to the internal reference gene $\beta$-actin.

Statistical analysis. Data are presented as the mean \pm SEM $(n=6)$. All statistical analyses were carried out by SPSS v21 (IBM Corp.). Comparisons among multiple groups were analyzed using one-way ANOVA followed by Tukey's post hoc test. $\mathrm{P}<0.05$ was considered to indicate a statistically significant difference.

\section{Results}

Effects of $\mathrm{KBrO}_{3}$ on ARPE-19 cell viability. Compared with the control group, incubation with $\mathrm{KBrO}_{3}$ for $24 \mathrm{~h}$ significantly inhibited ARPE-19 cell viability in a concentration-dependent manner $\mathrm{KBrO}_{3}$ decreased cell viability, and increased cell apoptosis and cell cytotoxicity at all three tested concentrations (Fig. 1A). The $\mathrm{Bcl} 2 / \mathrm{Bax}$ ratio is a useful index for 
evaluating $\mathrm{KBrO}_{3}$-induced apoptosis (25). $\mathrm{KBrO}_{3}$ significantly decreased the $\mathrm{Bcl} 2 / \mathrm{Bax}$ ratio in a concentration-dependent manner compared with the control group (Fig. 1B). Caspase-3 activity also serves as a biomarker of apoptosis (26). $\mathrm{KBrO}_{3}$ significantly decreased Caspase- 3 expression levels in a concentration-dependent manner compared with the control group (Fig. 1C). The results were further supported by the results of the $\mathrm{LDH}$ assay that demonstrated that $\mathrm{KBrO}_{3}$ significantly increased cell cytotoxicity in a concentration-dependent manner compared with the control group (Fig. 1D). In contrast to the other 2 pro-oxidants (4-NHE, $\mathrm{H}_{2} \mathrm{O}_{2}$ ), $\mathrm{KBrO}_{3}$ showed lower cell toxicity at $25 \mu \mathrm{M}$. Moreover, $75 \mu \mathrm{M} \mathrm{KBrO}_{3}$ and $30 \mu \mathrm{M}$ 4-HNE, which has been widely used to induce oxidative stress in RPE cells, displayed similar effects on ARPE-19 cells (23).

Effects of $\mathrm{KBrO}_{3}$ on oxidative stress biomarkers in ARPE-19 cells. In ARPE-19 cells, $\mathrm{KBrO}_{3}$ significantly inhibited the activities of antioxidant enzymes, including SOD or GSHPx, in a concentration-dependent manner compared with the control group (Fig. 2A and B). Therefore, the results indicated that $\mathrm{KBrO}_{3}$ induced oxidative stress in ARPE-19 cells.

To determine intracellular superoxide levels in ARPE-19 cells, DCFH-DA was used to detect intracellular ROS levels and DHE was used to detect intracellular superoxide levels. Compared with the control group, $\mathrm{KBrO}_{3}$ treatment significantly elevated ROS and superoxide levels (Fig. 2C and D). $\mathrm{KBrO}_{3}$-mediated effects were significantly inhibited by the antioxidants tiron and phloroglucinol in a concentration-dependent manner (Fig. 2C and D).

Inhibitory effects of antioxidants on $\mathrm{KBrO}_{3}$-mediated effects in ARPE-19 cells. Intracellular ROS levels were measured using the DCFH-DA fluorescence probe. Compared with the control group, $\mathrm{KBrO}_{3}$ significantly increased intracellular ROS levels in a concentration-dependent manner (Fig. 3A). Additionally, the effects of $\mathrm{KBrO}_{3}$ on intracellular ROS levels were significantly inhibited by the antioxidants tiron and phloroglucinol (Fig. 3B and C).

Moreover, compared with the control group, $\mathrm{KBrO}_{3}$ notably increased Bax protein expression levels in ARPE-19 cells. The antioxidant phloroglucinol markedly inhibited $\mathrm{KBrO}_{3}$-induced Bax protein expression levels in a concentration-dependent manner (Fig. 3E). Additionally, phloroglucinol reversed $\mathrm{KBrO}_{3}$-mediated downregulation of $\mathrm{Bcl} 2$ protein expression levels in ARPE-19 cells (Fig. 3E). Therefore, phloroglucinol significantly attenuated $\mathrm{KBrO}_{3}$-mediated downregulation of the Bcl2/Bax ratio in ARPE-19 cells (Fig. 3E). The antioxidant tiron displayed similar effects on the Bcl2/Bax ratio (Fig. 3D). The results indicated that antioxidants inhibited $\mathrm{KBrO}_{3}$-mediated effects on apoptotic factors in ARPE-19 cells.

Role of 4-HNE in $\mathrm{KBrO}_{3}$-mediated effects. $\mathrm{KBrO}_{3}$-induced apoptosis might be mediated via endogenous 4-HNE in ARPE-19 cells, as 4-HNE is produced in RPE cells during high oxygen consumption (27). Recently, 4-HNE was reported to serve as an agonist of the nicotinic receptor GPR109A (28). Therefore, 293 cells lacking the GPR109A gene (29) were used to investigate the effects of $\mathrm{KBrO}_{3}$.
Compared with the control group, the three tested concentrations of $\mathrm{KBrO}_{3}$ significantly inhibited 293 cell viability in a concentration-dependent manner (Fig. 4A), although the effective dose was higher and the incubation time was two-fold higher in 293 cells compared with ARPE-19 cells. However, compared with the control group, 4-HNE failed to significantly inhibit 293 cell viability at a concentration sufficient to inhibit ARPE-19 cell viability. Additionally, compared with the control group, $\mathrm{KBrO}_{3}$ significantly induced 293 cell apoptosis, but 4-HNE did not significantly alter 293 cell apoptosis as demonstrated by significantly increased caspase-3 expression levels in $\mathrm{KBrO}_{3}$-treated cells compared with control cells, but no significant alteration in caspase-3 expression levels in 4-HNE-treated cells compared with control cells (Fig. 4B). $\mathrm{KBrO}_{3}$ showed higher apoptosis induction in all fractionated doses in contrast to 4-HNE. Similarly, $\mathrm{KBrO}_{3}$ significantly increased cytotoxicity in 293 cells compared with the control group, but 4-HNE did not significantly increase cytotoxicity in 293 cells (Fig. 4C). Moreover, the antioxidant tiron significantly increased the $\mathrm{Bcl} 2 / \mathrm{Bax}$ ratio in $\mathrm{KBrO}_{3}$-treated 293 cells in a concentration-dependent manner (Fig. 4D). Therefore, the results suggested that 4-HNE did not serve a role in $\mathrm{KBrO}_{3}$-induced apoptosis.

Effects of $\mathrm{KBrO}_{3}$ on VEGF expression in ARPE-19 cells. Choroidal neovascularization (CNV) occurs during AMD, and VEGF is a critical signal in AMD-associated CNV (30). ROS inhibition may reduce VEGF mRNA expression levels (31). Therefore, alterations in VEGF mRNA expression levels in ARPE-19 cells treated with $\mathrm{KBrO}_{3}$ for $48 \mathrm{~h}$ were investigated.

Compared with the control group, $\mathrm{KBrO}_{3}$ significantly increased VEGF mRNA expression levels in a concentration-dependent manner at concentrations sufficient to induce ROS production (Fig. 5A). The upstream STAT3 may enhance VEGF gene expression (32). Compared with the control group, $\mathrm{KBrO}_{3}$ treatment also significantly increased STAT3 phosphorylation (Fig. 5B), which was inhibited by tiron. Cells were pretreated with stattic $(0.5$ and $1 \mu \mathrm{M}$; Sigma-Aldrich; Merck KGaA) for 30 min prior to addition of $\mathrm{KBrO}_{3}$. Stattic significantly attenuated $\mathrm{KBrO}_{3}$-mediated upregulation of VEGF mRNA expression levels (Fig. 5C). However, stattic failed to inhibit $\mathrm{KBrO}_{3}$-induced ROS production (Fig. 5D). Therefore, the results suggested that $\mathrm{KBrO}_{3}$ activated STAT3 via ROS to promote VEGF expression in ARPE-19 cells.

\section{Discussion}

The present study identified a novel AMD-like model using $\mathrm{KBrO}_{3}$ to induce oxidative stress in ARPE-19 cells. In the present study, $\mathrm{KBrO}_{3}$-induced cell injury was reversed by antioxidants. Moreover, the results suggested that $\mathrm{KBrO}_{3}$ induced apoptosis without mediating endogenous 4-HNE in ARPE-19 cells.

$\mathrm{KBrO}_{3}$ is an established oxidant (18), although to the best of our knowledge, its effects on ARPE-19 cells have not been previously reported. Oxidants, including $\mathrm{H}_{2} \mathrm{O}_{2}$ and t-BHP, have been reported to produce ROS in cells $(12,13,16)$. In the present study, $\mathrm{KBrO}_{3}$ significantly induced $\mathrm{ROS}$ production and apoptosis in ARPE-19 cells in a concentration-depended 

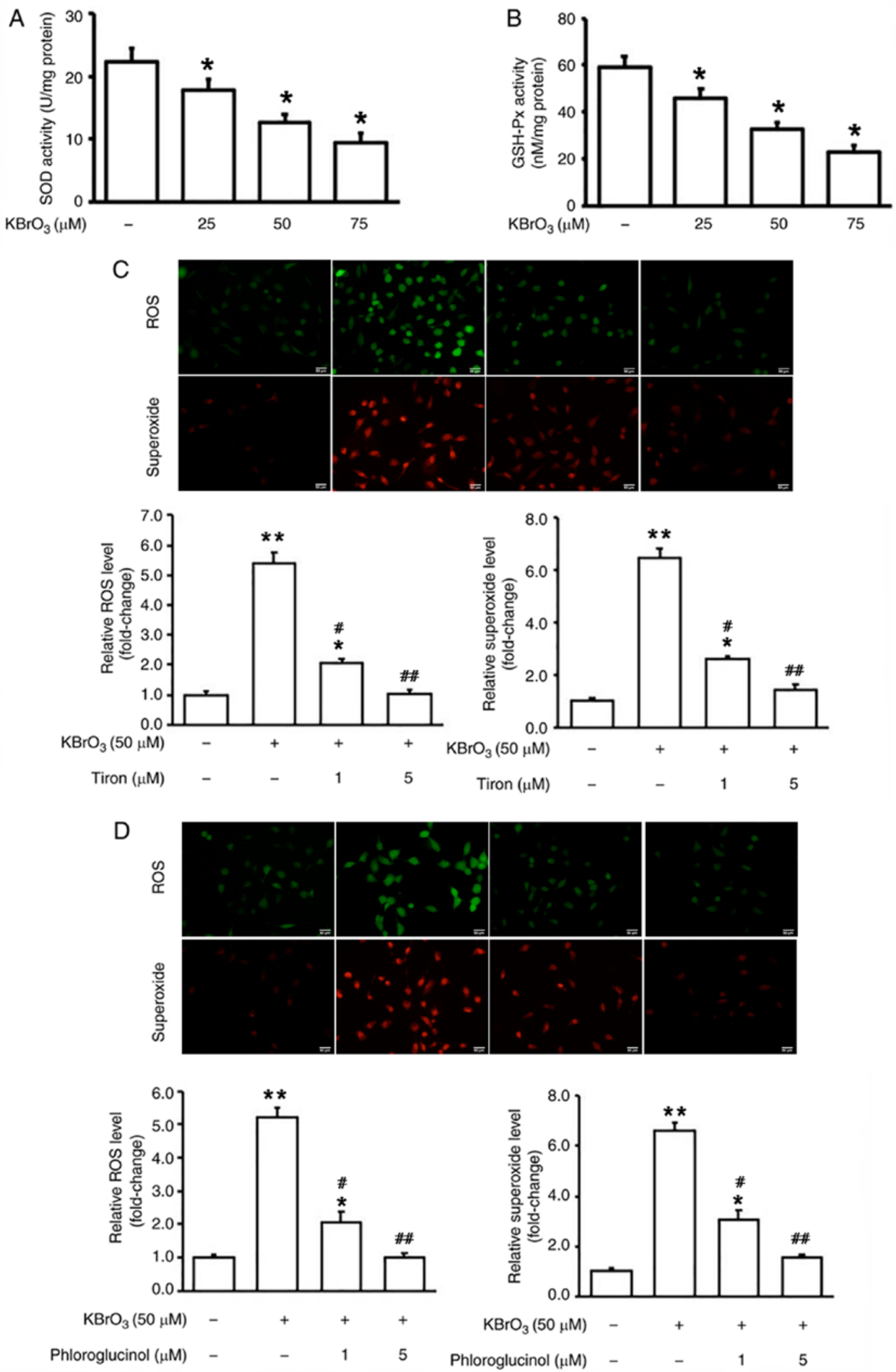

Figure 2. $\mathrm{KBrO}_{3}$-mediated effects on oxidative stress biomarkers in ARPE-19 cells. ARPE-19 cells were incubated with $\mathrm{KBrO}_{3}$ for 24 h. Effect of $\mathrm{KBrO}_{3}$ on (A) SOD and (B) GSHPx activities in ARPE-19 cells. Effects of the antioxidants (C) tiron and (D) phloroglucinol on $\mathrm{KBrO}_{3}$-induced oxidative stress. Data are presented as the mean \pm SEM $(n=6)$. ${ }^{*} \mathrm{P}<0.05$ and ${ }^{* *} \mathrm{P}<0.01$ vs. control; ${ }^{\#} \mathrm{P}<0.05$ and ${ }^{\# \#} \mathrm{P}<0.01$ vs. $\mathrm{KBrO}_{3}$. KBrO $\mathrm{KB}_{3}$, potassium bromate; $\mathrm{SOD}$, superoxide dismutase; GSHPx, glutathione peroxidase; ROS, reactive oxygen species.

manner. RPE cells may digest photoreceptor POSs (10); however, oxidative stress reduces the digestive rate of POS (10), and higher POS results in lipofuscin formation, one of the major alterations associated with AMD (11). Therefore, the present study indicated that $\mathrm{KBrO}_{3}$ may be useful to establish a cell model of AMD in ARPE-19 cells. 


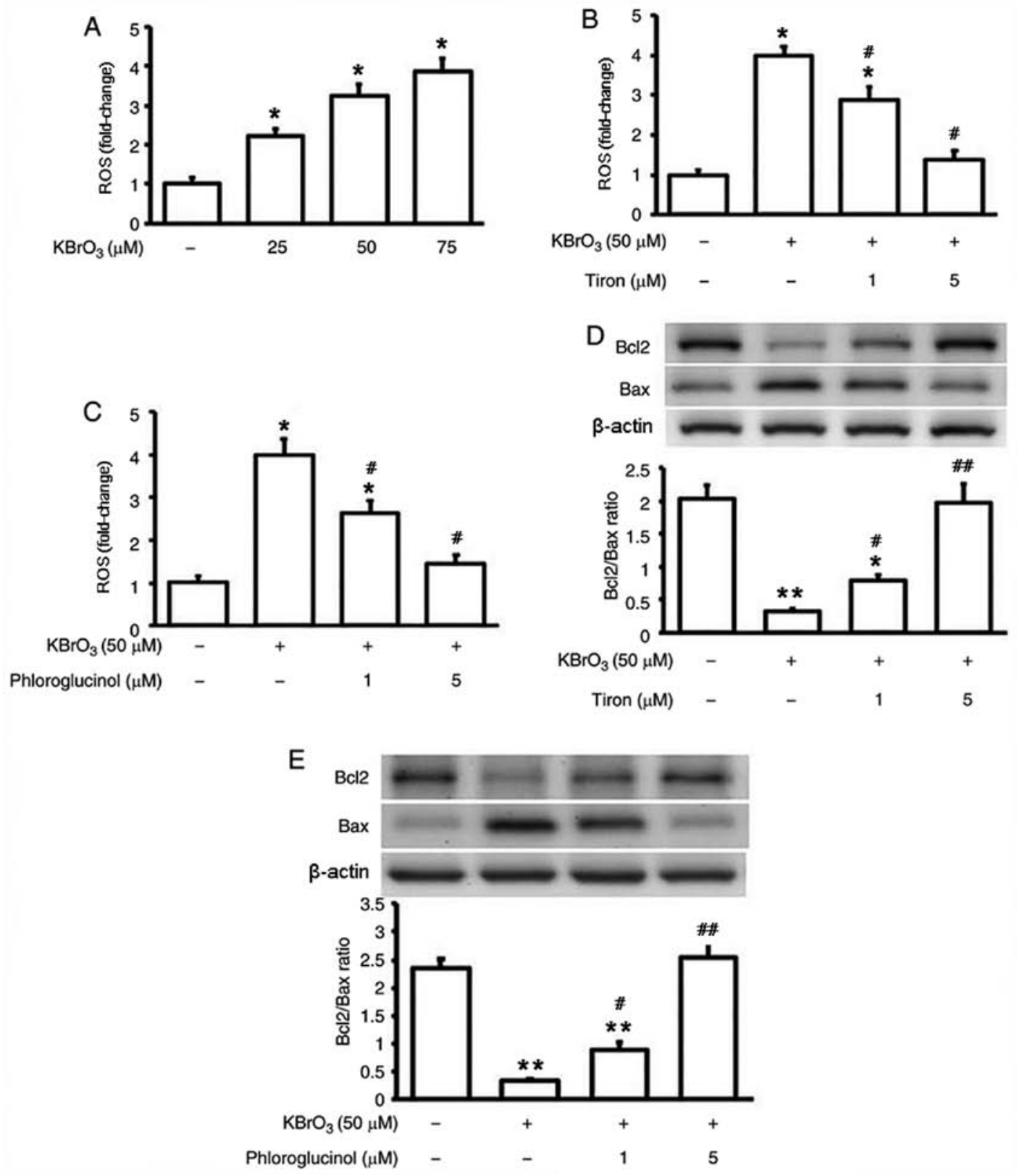

Figure 3. $\mathrm{KBrO}_{3}$ induces ARPE-19 cell apoptosis. (A) Effect of $\mathrm{KBrO}_{3}$ on intracellular ROS levels in ARPE-19 cells. Effects of the antioxidants (B) tiron and (C) phloroglucinol on $\mathrm{KBrO}_{3}$-induced intracellular ROS levels in ARPE-19 cells. Effects of the antioxidants (D) tiron and (E) phloroglucinol on $\mathrm{KBrO}_{3}$-induced ARPE-19 cell apoptosis were determined by measuring the Bcl2/Bax ratio. Data are presented as the mean $\pm \mathrm{SEM}(\mathrm{n}=6)$. ${ }^{*} \mathrm{P}<0.05$ and ${ }^{* *} \mathrm{P}<0.01$ vs. control; ${ }^{\#} \mathrm{P}<0.05$ and ${ }^{\# \#} \mathrm{P}<0.01$ vs. $\mathrm{KBrO}_{3} . \mathrm{KBrO}_{3}$, potassium bromate; $\mathrm{ROS}$, reactive oxygen species.

Similar to other oxidants, in the present study, $\mathrm{KBrO}_{3}$ significantly increased cytotoxicity in ARPE-19 cells compared with the control group. Moreover, compared with the control group, $\mathrm{KBrO}_{3}$ inhibited ARPE-19 cell viability in a dose-dependent manner at the tested concentrations $(25,50$ and $75 \mu \mathrm{M})$. At $75 \mu \mathrm{M}, \mathrm{KBrO}_{3}$ induced ARPE-19 cell apoptosis to a similar level to ARPE-19 cell apoptosis induced by $30 \mu \mathrm{M} 4$ 4-HNE. Also, 4-HNE produced in the RPE during high oxygen consumption is associated with AMD (33). Therefore, 4-HNE was used as a reference in the present study. Treatment with at higher concentrations $(30 \mu \mathrm{M})$ causes cytotoxicity and ROS formation effect in cells compared with that in $\mathrm{KBrO}_{3}$ $(25 \mu \mathrm{M})$ (34). In addition, t-BHP has been reported to induce cell apoptosis at doses $>250 \mu \mathrm{M}$ (14). In RPE cells, exposure to $1 \mathrm{mM} \mathrm{H}_{2} \mathrm{O}_{2}$ for $24 \mathrm{~h}$ markedly inhibited viability compared with the control group $(12,13)$. Therefore, the results of the present study suggested that $\mathrm{KBrO}_{3}$ might be more potent than the aforementioned oxidants in ARPE-19 cells.

It has been reported that $\mathrm{KBrO}_{3}$-induced apoptosis is mediated via endogenous 4-HNE in ARPE-19 cells (33). 4-HNE is effective as an agonist for the nicotinic receptor GPR109A (28), thus 293 cells, which lack GPR109A expression (29), were used in the present study. In 293 cells, compared with the control group, $\mathrm{KBrO}_{3}$ significantly induced apoptosis and cytotoxicity, but 4-HNE did not display these effects. Therefore, the results suggested that endogenous 4-HNE was not involved in $\mathrm{KBrO}_{3}$-induced apoptosis.

The present study demonstrated that $\mathrm{KBrO}_{3}$ induced oxidative stress, which promoted cytotoxicity and apoptosis in ARPE-19 cells, but $\mathrm{KBrO}_{3}$-mediated effects were reversed by 

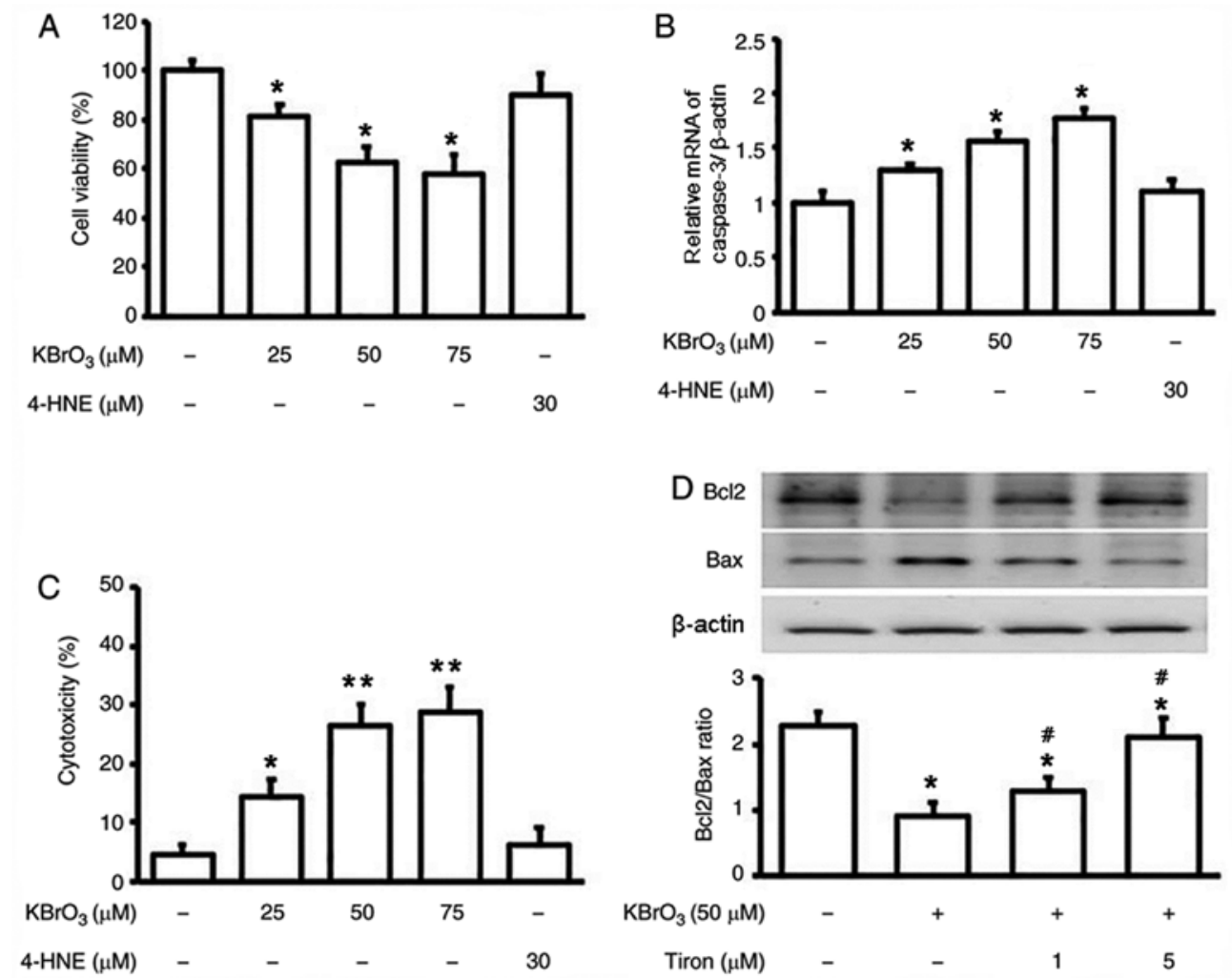

Figure 4. Effect of 4-HNE on $\mathrm{KBrO}_{3}$-induced injury in 293 cells. (A) Cell viability was assessed by performing the MTT assay. (B) Cell apoptosis was assessed by measuring caspase-3 mRNA expression levels. (C) Cell viability was also assessed by performing the lactate dehydrogenase assay. (D) Effect of the antioxidants tiron on $\mathrm{KBrO}_{3}$-induced 293 cell apoptosis. Data are presented as the mean $\pm \mathrm{SEM}(\mathrm{n}=6) .{ }^{*} \mathrm{P}<0.05$ and ${ }^{* *} \mathrm{P}<0.01$ vs. control; ${ }^{*} \mathrm{P}<0.05$ vs. $\mathrm{KBrO}{ }_{3}$. 4-HNE, 4-hydroxynonenal; $\mathrm{KBrO}_{3}$, potassium bromate.

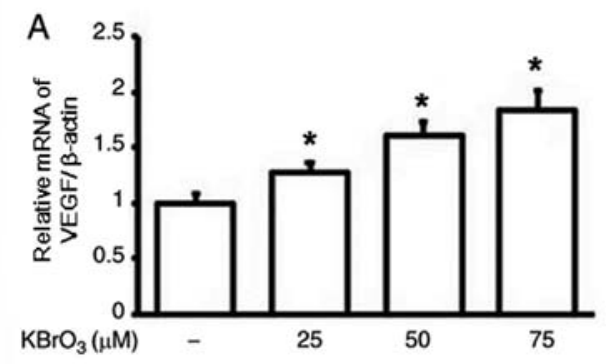

B p-STAT3
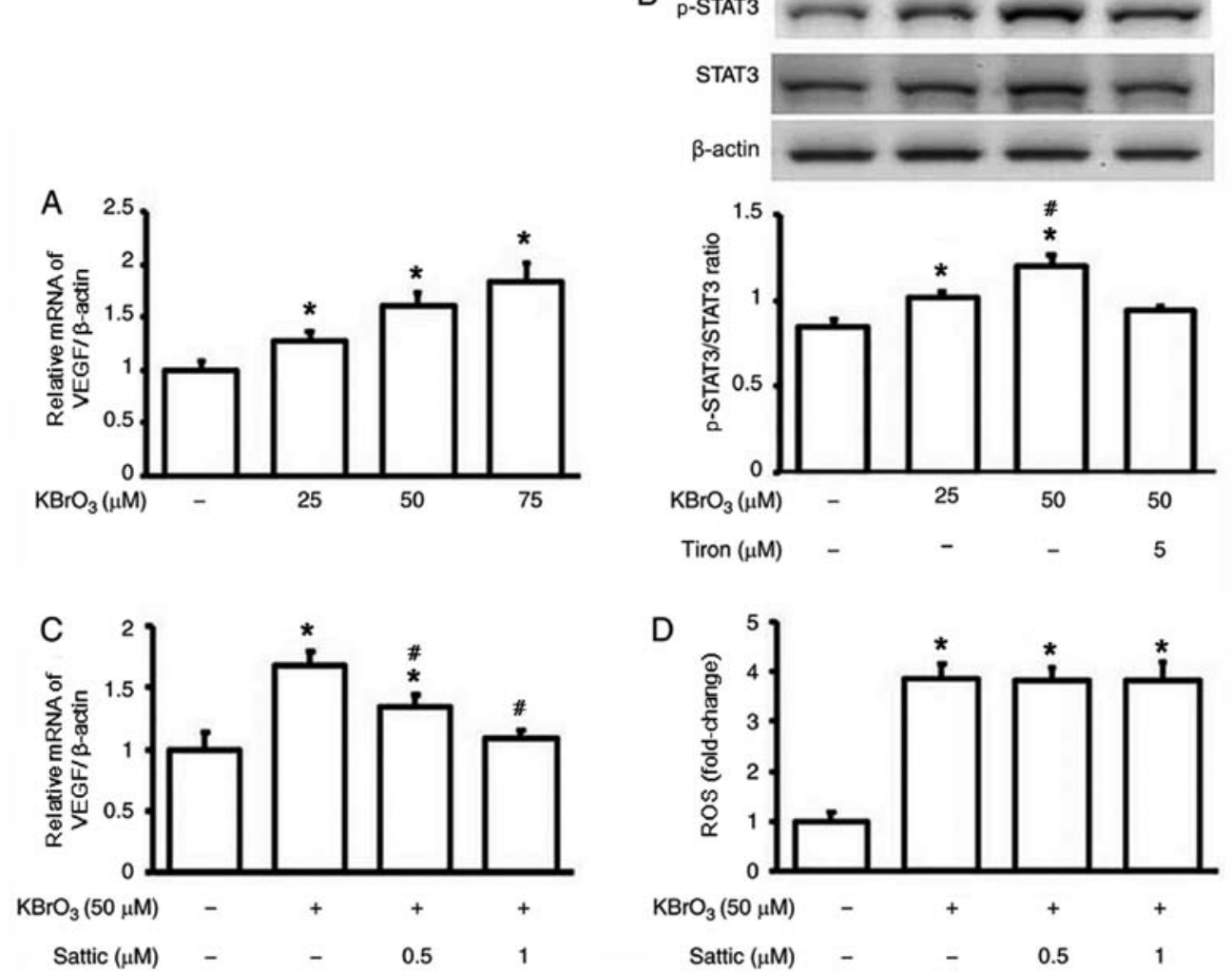

Figure 5. Effect of $\mathrm{KBrO}_{3}$ on VEGF expression in ARPE-19 cells. (A) Effect of $\mathrm{KBrO}_{3}$ on VEGF mRNA expression levels in ARPE-19 cells. (B) Effect of $\mathrm{KBrO}_{3}$ on STAT3 activation in ARPE-19 cells. The antioxidant tiron reversed $\mathrm{KBrO}_{3}$-mediated effects on STAT3 activation in ARPE-19 cells. Effect of static on $\mathrm{KBrO}_{3}$-mediated (C) VEGF mRNA expression levels and (D) ROS production in ARPE-19 cells. Data are presented as the mean \pm SEM ( $\mathrm{n}=6$ ). ${ }^{*} \mathrm{P}<0.05$ vs. control; ${ }^{~} \mathrm{P}<0.05$ vs. $\mathrm{KBrO}_{3} . \mathrm{KBrO}_{3}$, potassium bromate; ROS, reactiveoxygen species; $\mathrm{p}$, phosphorylated. 
treatment with the antioxidants tiron and phloroglucinol. Tiron is a mitochondria-targeted antioxidant (35) and phloroglucinol protects RPE (36). The mediation of ROS in $\mathrm{KBrO}_{3}$-treated ARPE cells was also increased in a concentration-dependent manner. Moreover, $\mathrm{KBrO}_{3}$ treatment significantly inhibited antioxidant enzyme activities, including SOD, GSHPx in ARPE-19 cells, suggesting that $\mathrm{KBrO}_{3}$-induced oxidative stress in ARPE-19 cells. This was consistent with previous studies using hepatic (18) and cardiac (19) cells.

CNV occurs during the 'wet' phase of AMD, which occurs during the late stages of the disease (37).Hyperglycemia-induced oxidative stress may induce activation of STAT3-regulated VEGF expression in RPE cells (38). In the present study, the results suggested that $\mathrm{KBrO}_{3}$ activated STAT3 to promote VEGF expression in ARPE-19 cells. The results indicated that oxidative stress mediated this effect as $\mathrm{KBrO}_{3}$-induced effects were reversed by antioxidants. Moreover, the STAT3 inhibitor stattic significantly attenuated $\mathrm{KBrO}_{3}$-induced upregulation of VEGF mRNA expression levels at a dose that failed to inhibit $\mathrm{KBrO}_{3}$-induced $\mathrm{ROS}$ production. Stattic is an established STAT3 inhibitor that is pharmacologically applied in vitro and in vivo (39). Collectively, the results indicated that $\mathrm{KBrO}_{3}$-induced oxidative stress may activate STAT3 to promote VEGF expression in ARPE-19 cells.

$\mathrm{KBrO}_{3}$ is easily prepared in solution for both in vitro and in vivo investigations (40). As an oxidative stress inducer in cells, $\mathrm{KBrO}_{3}$ displays improved stability compared with $\mathrm{H}_{2} \mathrm{O}_{2}$ (41). However, the application of $\mathrm{KBrO}_{3}$ in animals may result in damage to the kidney when injury is initiated (42), whereas the ROS scavenger rutin may inhibit $\mathrm{KBrO}_{3}$ (43). Therefore, systemic application of $\mathrm{KBrO}_{3}$ to induce AMD may be difficult to achieve in animals. However, local application of $\mathrm{KBrO}_{3}$ in the eye may serve as an alternative method to prepare AMD model animals, but further investigation is required.

In conclusion, the present study identified a novel method to establish an AMD cell model using $\mathrm{KBrO}_{3}$ as an oxidant in ARPE-19 cells. $\mathrm{KBrO}_{3}$ treatment may serve as a simple and useful method to induce AMD cell models in the future.

\section{Acknowledgements}

The authors would like to thank laboratory assistants of Chi-Mei Medical Center, Ms. Y.L. Yen and Ms. Y.P. Lin, for their kind help with the experiments.

\section{Funding}

No funding was received.

\section{Availability of data and materials}

The datasets used and/or analyzed during the current study are available from the corresponding author on reasonable request.

\section{Authors' contributions}

SCK and JTC designed the study and analyzed the data. YL assisted with performing the experiments and prepared the manuscript. JTC supervised the project. $\mathrm{CCH}$ analyzed the data and prepared the manuscript. KCC analyzed the data and revised the manuscript. HHL contributed to the study design and performed the VEGF assay. All authors read and approved the final manuscript.

\section{Ethics approval and consent to participate}

Not applicable.

\section{Patient consent for publication}

Not applicable.

\section{Competing interests}

The authors declare that they have no competing interests.

\section{References}

1. Datta S, Cano M, Ebrahimi K, Wang L and Handa JT: The impact of oxidative stress and inflammation on RPE degeneration in non-neovascular AMD. Prog Retin Eye Res 60: 201-218, 2017.

2. van Lookeren Campagne M, LeCouter J, Yaspan BL and Ye W: Mechanisms of age-related macular degeneration and therapeutic opportunities. J Pathol 232: 151-164, 2014.

3. Jager RD, Mieler WF and Miller JW: Age-related macular degeneration. N Engl J Med 358: 2606-2617, 2008.

4. Chen Y, Bedell M and Zhang K: Age-related macular degeneration: Genetic and environmental factors of disease. Mol Interv 10: 271-281, 2010.

5. Coleman HR, Chan CC, Ferris FL III and Chew EY: Age-related macular degeneration. Lancet 372: 1835-1845, 2008.

6. Bhutto I and Lutty G: Understanding age-related macular degeneration (AMD): Relationships between the photoreceptor/ retinal pigment epithelium/Bruch's membrane/choriocapillaris complex. Mol Aspects Med 33: 295-317, 2012.

7. Ding X, Patel M and Chan CC: Molecular pathology of age-related macular degeneration. Prog Retin Eye Res 28: 1-18, 2009.

8. Lorés-Motta L, de Jong EK and den Hollander AI: Exploring the use of molecular biomarkers for precision medicine in age-related macular degeneration. Mol Diagn Ther 22: 315-343, 2018.

9. Bonilha VL: Oxidative Stress Regulation and DJ-1 Function in the Retinal Pigment Epithelium: Implications for AMD. Adv Exp Med Biol 1074: 3-9, 2018

10. Liang FQ and Godley BF: Oxidative stress-induced mitochondrial DNA damage in human retinal pigment epithelial cells: A possible mechanism for RPE aging and age-related macular degeneration. Exp Eye Res 76: 397-403, 2003.

11. Wihlmark U, Wrigstad A, Roberg K, Brunk UT and Nilsson SE: Lipofuscin formation in cultured retinal pigment epithelial cells exposed to photoreceptor outer segment material under different oxygen concentrations. APMIS 104: 265-271, 1996.

12. Hu X, Liang Y, Zhao B and Wang Y: Thymoquinone protects human retinal pigment epithelial cells against hydrogen peroxide induced oxidative stress and apoptosis. J Cell Biochem 120: 4514-4522, 2019.

13. Lu L, Hackett SF, Mincey A, Lai H and Campochiaro PA: Effects of different types of oxidative stress in RPE cells. J Cell Physiol 206: 119-125, 2006.

14. Shen C, Ma W, Zheng W, Huang H, Xia R, Li C and Zhu X: The antioxidant effects of riluzole on the APRE-19 celll model injury-induced by t-BHP. BMC Ophthalmol 17: 210, 2017.

15. Abdel-Wahab WM: Thymoquinone attenuates toxicity and oxidative stress induced by bisphenol A in liver of male rats. Pak J Biol Sci 17: 1152-1160, 2014.

16. Sheu SJ, Chao YM, Liu NC and Chan JY: Differential effects of bevacizumab, ranibizumab and aflibercept on cell viability, phagocytosis and mitochondrial bioenergetics of retinal pigment epithelial cell. Acta Ophthalmol 93: e631-e643, 2015.

17. Cunningham DK and Anderson JA: Decomposition of bromate in fermenting and nonfermenting doughs. Cereal Chem 33: 290-299, 1956. 
18. Zhang Y, Jiang L, Jiang L, Geng C, Li L, Shao J and Zhong L: Possible involvement of oxidative stress in potassium bromate-induced genotoxicity in human HepG2 cells. Chem Biol Interact 189: 186-191, 2011.

19. Kuo SC, Li Y, Cheng YZ, Lee WJ, Cheng JT and Cheng KC: Molecular mechanisms regarding potassium bromate induced cardiac hypertrophy without apoptosis in H9c2 cells. Mol Med Rep 18: 4700-4708, 2018.

20. Watanabe S, Togashi S and Fukui T: Contribution of nitric oxide to potassium bromate-induced elevation of methaemoglobin concentration in mouse blood. Biol Pharm Bull 25: 1315-1319, 2002.

21. Li CJ, Lv L, Li H and Yu DM: Cardiac fibrosis and dysfunction in experimental diabetic cardiomyopathy are ameliorated by alpha-lipoic acid. Cardiovasc Diabetol 11: 73, 2012.

22. Liu WY, Liou SS, Hong TY and Liu IM: The benefits of the citrus flavonoid diosmin on human retinal pigment epithelial cells under high-glucose conditions. Molecules 22: 2251, 2017.

23. Hytti M, Piippo N, Salminen A, Honkakoski P, Kaarniranta K and Kauppinen A: Quercetin alleviates 4-hydroxynonenal-induced cytotoxicity and inflammation in ARPE-19 cells. Exp Eye Res 132: 208-215, 2015

24. Livak KJ and Schmittgen TD: Analysis of relative gene expression data using real-time quantitative PCR and the 2(-Delta Delta C(T)) method. Methods 25: 402-408, 2001.

25. Salakou S, Kardamakis D, Tsamandas AC, Zolota V, Apostolakis E, Tzelepi V, Papathanasopoulos P, Bonikos DS, Papapetropoulos T, Petsas T, et al: Increased Bax/Bcl-2 ratio up-regulates caspase-3 and increases apoptosis in the thymus of patients with myasthenia gravis. In Vivo 21: 123-132, 2007.

26. Wang Y, Shen D, Wang VM, Yu CR, Wang RX, Tuo J and Chan CC: Enhanced apoptosis in retinal pigment epithelium under inflammatory stimuli and oxidative stress. Apoptosis 17: 1144-1155, 2012.

27. Sharma A, Sharma R, Chaudhary P, Vatsyayan R, Pearce V, Jeyabal PV, Zimniak P, Awasthi $S$ and Awasthi YC: 4-Hydroxynonenal induces p53-mediated apoptosis in retinal pigment epithelial cells. Arch Biochem Biophys 480: 85-94, 2008

28. Gautam J, Banskota S, Shah S, Jee JG, Kwon E, Wang Y, Kim DY, Chang HW and Kim JA: 4-Hydroxynonenal-induced GPR109A (HCA2 receptor) activation elicits bipolar responses, Gai-mediated anti-inflammatory effects and G $\beta \gamma$-mediated cell death. Br J Pharmacol 175: 2581-2598, 2018

29. Li G, Shi Y, Huang H, Zhang Y, Wu K, Luo J, Sun Y, Lu J, Benovic JL and Zhou N: Internalization of the human nicotinic acid receptor GPR109A is regulated by G(i), GRK2, and arrestin3. J Biol Chem 285: 22605-22618, 2010.

30. Wang X, Ma W, Han S, Meng Z, Zhao L, Yin Y, Wang Y and Li J: TGF- $\beta$ participates choroid neovascularization through Smad2/3-VEGF/TNF- $\alpha$ signaling in mice with Laser-induced wet age-related macular degeneration. Sci Rep 7: 9672, 2017.
31. Ushio-Fukai M and Nakamura Y: Reactive oxygen species and angiogenesis: NADPH oxidase as target for cancer therapy. Cancer Lett 266: 37-52, 2008

32. Wei D, Le X, Zheng L, Wang L, Frey JA, Gao AC, Peng Z, Huang S, Xiong HQ, Abbruzzese JL, et al: Stat3 activation regulates the expression of vascular endothelial growth factor and human pancreatic cancer angiogenesis and metastasis. Oncogene 22: 319-329, 2003

33. Ethen CM, Reilly C, Feng X, Olsen TW and Ferrington DA: Age-related macular degeneration and retinal protein modification by 4-hydroxy-2-nonenal. Invest Ophthalmol Vis Sci 48: 3469-3479, 2007

34. Raza $\mathrm{H}$ and John A: 4-hydroxynonenal induces mitochondrial oxidative stress, apoptosis and expression of glutathione $\mathrm{S}$-transferase A4-4 and cytochrome P450 2E1 in PC12 cells. Toxicol Appl Pharmacol 216: 309-318, 2006.

35. Oyewole AO and Birch-Machin MA: Mitochondria-targeted antioxidants. FASEB J 29: 4766-4771, 2015.

36. Cia D, Cubizolle A, Crauste C, Jacquemot N, Guillou L, Vigor C, Angebault C, Hamel CP, Vercauteren J and Brabet P: Phloroglucinol protects retinal pigment epithelium and photoreceptor against all-trans-retinal-induced toxicity and inhibits A2E formation. J Cell Mol Med 20: 1651-1663, 2016.

37. Calabrèse A, Bernard JB, Hoffart L, Faure G, Barouch F, Conrath $\mathrm{J}$ and Castet $\mathrm{E}$ : Wet versus dry age-related macular degeneration in patients with central field loss: Different effects on maximum reading speed. Invest Ophthalmol Vis Sci 52: 2417-2424, 2011

38. Li X, Cai Y, Wang YS, Shi YY, Hou W, Xu CS, Wang HY, Ye Z, Yao LB and Zhang J: Hyperglycaemia exacerbates choroidal neovascularisation in mice via the oxidative stress-induced activation of STAT3 signalling in RPE cells. PLoS One 7: e47600, 2012.

39. Dural E, Shah UK, Pritchard D, Chapman KE, Doak SH and Jenkins GJ: The effect of chronic dosing and p53 status on the genotoxicity of pro-oxidant chemicals in vitro. Mutagenesis geaa024, 2020.

40. Kurokawa Y, Maekawa A, Takahashi M and Hayashi Y: Toxicity and carcinogenicity of potassium bromate--a new renal carcinogen. Environ Health Perspect 87: 309-335, 1990.

41. Parsons JL and Chipman JK: The role of glutathione in DNA damage by potassium bromate in vitro. Mutagenesis 15: 311-316, 2000.

42. Giri U, Iqbal $\mathrm{M}$ and Athar M: Potassium bromate $\left(\mathrm{KBrO}_{3}\right)$ induces renal proliferative response and damage by elaborating oxidative stress. Cancer Lett 135: 181-188, 1999.

43. Khan RA, Khan MR and Sahreen S: Protective effects of rutin against potassium bromate induced nephrotoxicity in rats. BMC Complement Altern Med 12: 204, 2012. 